\title{
Translating in Canada: An Interview with Literary Translator and Translation Scholar Dr. Luise von Flotow
}

\author{
Anna Antonova \\ University of Alberta, Canada
}

The interviewee, Dr. Luise von Flotow, is a Professor of Translation Studies and was the Director of School of Translation and Interpretation at the University of Ottawa from 2006 to 2016. She is also a prolific literary translator from German, French, and Spanish. Dr. von Flotow is best known as the author of her 1997 monograph Translation and Gender: Translating in the "Era of Feminism" and the editor of translation anthologies, Translating Women (2011) and Translating Women: Different Voices and New Horizons (2017). Her research interests include gender issues in translation, transnational feminism in translation studies, political and ideological aspects of translation, and cultural diplomacy. Dr. von Flotow was interviewed by Anna Antonova, a third-year PhD student at the Department of Modern Languages and Cultural Studies, University of Alberta.

Anna Antonova: Thank you for meeting with me, Dr. von Flotow. The first thing I wanted to ask you about is how did your interest in translation start? What was the most memorable thing that started it off for you, as a translator and an academic?

Luise von Flotow: Well, it developed over time. And I think it started from growing up in a bilingual situation. It was stimulating for me as a child to speak German at home, and English at school, and to have to reconcile those two languages, but also cultures, which were very far apart in the 1950s. My actual work in literary translation did not start until I was back in Canada after living abroad and finishing my undergraduate studies. When I returned, I got into Canadian literature studies, and I saw translation as a real option to become involved in literary activities. At the time, I had small children, and translation was the one thing I could do on the side, in my free time, that did not require me hiring a babysitter. It was something I could do while my children were sleeping. Plus, I was also getting back into French, which I had studied as an undergrad but had to neglect as a young mother. Getting back into French meant studying Quebec. I participated in a six-week summer language course at one of the universities, and developed a real interest in contemporary Quebec writing, which at the time, in the late 1970s and early 1980s, had a strong feminist component. For me as a young mom stuck at home with four kids, this was pretty inspirational. And that was what I translated.

AA: Were those translations from French into English?

LF: Yes. My first two translations were published in the Canadian Fiction Magazine. It was just bringing out a special issue on contemporary Quebec writing entitled A Decade of Quebec Fiction. 
Quebec was booming in terms of literary development. That was my first Anglophone Canadian publishing venture, those two translations.

AA: So, what were those first texts?

LF: Two short stories by Madeleine Ouellette-Michalska. And then I went on to translate an entire collection of her short stories, La Femme de sable.

AA: And what are you working on now?

LF: I am just finishing the work on and setting up the launch for a book on Ulrike Meinhof that I helped translate into French. I was involved in the first English version of that book, translating the political columns written by Meinhof. She was a German liberal, left-wing, and increasingly feminist journalist in the 1960s, who garnered a lot of attention and respect at the time, which was quite remarkable for a woman in that context. But in 1970 she went underground and became a member of the Red Army Faction, more the intellectual driving force of that group than an actual terrorist. Karin Bauer at McGill University developed a book about her that was titled Everybody Talks about the Weather. We Don't! (NYC, Seven Stories Publishing, 2008). She did the research and wrote a long introduction about Ulrike Meinhof and her times, while I translated Meinhof's political columns. Now, over the last couple of years, we have translated the whole book from English into French. It was an interesting experience to see the columns that I had translated from German into English being re-translated from my English into French. There was a lot of work to do going back to the German original and correcting the French translation. So this was my role. The book is coming out on November 13 in Montreal under the title Tout le monde parle de la pluie et du beau temps. Pas nous. (Montreal, Editions Remue-ménage, 2018).

AA: This sounds like a unique project, a re-translation of the previous translation that still refers back to the original.

LF: It was super interesting! The French translation was actually done by a professional translator who initiated the project. So the three of us, Isabelle Totikaev, the French translator, Karin Bauer, the editor of the original book, and I, met at a centre for translators and writers in Greece and spent two weeks going over the translation into French and checking it against the German. There is a wonderful place there where writers and translators can meet to work together. I am going there again in October, to work on a new project.

AA: What is it this time?

LF: It is a German book called Die Welt im Rücken. It is about bipolar disorder, and focuses on the narrator's three strong episodes of manic madness and depression. It is written in a very wideranging literary style. I just signed the contract for this translation with Biblioasis. 
AA: It would be interesting to know how you choose texts for your translation projects. Or is it the other way around, and the publishers choose you?

LF: I choose the texts. Especially with German, it would be very difficult to wait for a publisher to invite you to translate. So little gets translated from German into English.

AA: So, you have to pitch the project to the publisher?

LF: Yes, and to do that in Canada is especially difficult because virtually all Canadian publishing houses are subsidized by the Government of Canada. The government of Canada supports translation between Canadian-French and Canadian-English, but not German or other languages. It is next to impossible to get anything else translated in Canada. Biblioasis is one of the very few publishers in Canada that has a translation series that includes other languages: Hungarian, Argentinian Spanish, Angolan Portuguese, Romanian, and now German. I have been in touch with them over the years proposing projects that I thought might be good, and they asked me to keep proposing until finally they decided to buy the rights and translate this book by Thomas Melle.

AA: So, they have to be interested in a particular project or a particular author. By the way, when you translate, how do you see your role and your relationship with the author? Do you ever reach out to the writers or talk to them to clarify some of the questions you might have?

LF: Yes, that is a very interesting part of the work. In the past I have quite deliberately translated mostly women writers. Thomas Melle, the author of this German book on bipolar disorder, is the first man that I am going to translate in a very long time. As for women writers, specifically France Théoret, who is an experimental writer from Quebec, I have met with her regularly to go over things that I marked in the text and needed help with. She was always very accommodating. Sometimes, though, writers cannot explain or do not remember what they meant in that particular spot you are having difficulty with. They write on the spur of the moment, and some things they cannot necessarily explain later, especially if there is a nine or ten year gap between the initial writing and the translation. I like meeting with writers, but it may not always be helpful.

AA: But would you say you see yourself as a co-author of the texts you translate?

LF: If you ask me whether I see myself as a co-author, no. Not at all. I see myself as rewriting the book in a completely different language and for a completely different audience. I do not think that is co-authorship.

AA: Yes, audience is a very important factor. In a way, the reader always co-authors the text because the reader is the one who constructs the message. 
LF: Yes. And I think that is important and interesting to think about. Intellectuals working in translation studies read differently than members of the general public who might not care that much about details. What readers largely care about is readability, and not theoretical questions that plague scholars. Translation is difficult enough.

AA: As for resistant translation that so many translation scholars are writing about, did you have any experiences with it? Did you ever write intentionally against the original text?

LF: Yes. I translated an East German writer once, Thomas Brasch—quite well-known and also a translator of Shakespeare. In that case, I remember, I was so annoyed by his masculinist pathos, by the things he wrote, that it was the last man's work I translated for a long time. First of all, I did make changes, but only small ones. Secondly, I never pursued getting the work published when Guernica said they could not do it (for lack of government funding). I just let it go. And I have not translated another male writer's work since then. In another case, this time a woman writer, I translated half of the text before I gave up, and said I couldn't do it: it was just too irritating! Translating effectively "against" a text can be difficult because such intervention is not usually visible. Resistant translation is only noticeable if you make it visible, if you write articles about it or remark on it in footnotes; only if you draw readers' attention to it, and the readers may not always find this fascinating. So I think resistant translation is something that we like to write about as academics and researchers, but it is difficult to do effectively.

AA: What about supplementing, prefacing, footnoting, and other marks of translator's visibility? Do you ever use these strategies in your translations? It seems that it is not often done by translators, although we often read about it.

LF: No, I tend not to use such strategies very much. However, for the Christa Wolf book that came out in 2011, They Divided the Sky (which was a re-translation of Der geteilte Himmed) I did write a preface. Usually you do not get this opportunity. When I wrote about feminist translation in Canada, those texts were deliberately prefaced-it was an extraordinary measure. And those were cases where translators often deliberately changed, or more often needed to explain the texts; they relied on the publisher's willingness to include prefaces. But that is not the rule, that is not what usually happens. In the case of the Christa Wolf translation, I was exceptionally able to include a preface, perhaps because it was a re-translation, done by a university press, and there was a whole complicated story to tell. Since that book came out, at least one article has been published that criticizes the existence of this preface. Caroline Summers, the author of that article ("World Authorship as a Struggle for Consecration: Christa Wolf and Der geteilte Himmel in the EnglishSpeaking World") argues that professor so-and-so wields her professorial and academic power in the preface to position the text in a certain way for a certain audience. When I read that, I thought, what an interesting and deliberate misunderstanding of my intentions! My impression is that the article 
claims I am abusing my status as a professor of translation studies to comment on the book and the author.

AA: What a way to put a translator down!

LF: Yes, rather than say that finally we get to hear from the translator directly. Most often you do not get to hear from them, because the translators do not have the time-or it is not worth their while to take the time- to write those complicated prefaces.

AA: From what I have seen, even when it is done, it is not often the translator who gets the space and opportunity. Prefaces are written by editors, critics, publishers, but not the translators.

LF: At the University of Ottawa, we have introduced a literary translation option where students and graduates of the MA translate between French and English and their translations are published by UOttawa Press (if the quality of the work allows this.) Because this is co-funded by the graduate school, the translators must include a preface. This is great, because finally, translators are being made visible, but also because they are translating great writers, such as Carol Shields, and Margaret Laurence. But this is the exception in publishing, not the rule.

AA: I remember that you wrote in Translation and Gender that the status of literary translators in Canada was not really lower than that of authors, and this was visible in the use of paratext. Do you still believe this to be true?

LF: This applied specifically to the feminist translations that were being completed and published in the 1980s and 1990s. Some people would still agree today. When you look at how literary translations are funded in Canada, you could argue that translators have an even better status than authors. Authors' funding is different. Of course, some of them are subsidized or get writing grants, but not everyone. Literary translators, on the other hand, once they have a contract that is subsidized by the Canada Council for the Arts, are paid 18 cents a word for their translations. In that regard, the argument has been made that translators are even more recognized and in a better position than the authors. But I think on the whole we still live in the world where the author counts more and is viewed as more important.

AA: Also, do you think that this situation is unique to Canada? I doubt that in the rest of the world translators get this kind of recognition and remuneration.

LF: No, here in Canada we are privileged. The translation business in Canada, especially literary translation inside Canada, can be quite comfortable with the amount of funding currently available. Still, the translation business is miniscule. In countries like Germany, Sweden, Norway, this business is huge, and translators can build careers from literary translation. They can also wield considerable power: a few years ago in Norway, for example, literary translators actually worked-to-rule to protest 
some aspect of their working conditions. They handed in their completed translations in hard copy only, not in digitized form, so that the publishing house had to either scan or retype everything. In those countries, literary translators' associations are strong and the perceived need for translations is very important. Publishers lose money if they do not get the translations out. Such work-to-rule tactics would have no effect in Canada, at all.

AA: So, you need to have an association or a professional union to get that kind of support.

LF: Yes, and you need readers who care. A strong union is hard to develop and maintain when there are many bilingual people, who are not necessarily professional translators and when there is not enough literary translation to keep such an association going, and recognized.

AA: That is another thing. Particularly in literary translation, it seems that many practicing translators have no professional background or knowledge of translation theory.

LF: Do you need to have knowledge of translation theory? I think it may help. There are so many decisions to make on every page, that to have an understanding of what has been written on the topic of translation, and what some theoretical approaches are, is useful. Theory also makes you aware of options, and of the assumptions upon which you base your decisions.

AA: It would be interesting to hear what you think about theoretical feminist writing on translation studies, particularly Canadian writing starting from the late 1970s. These works have really been influential, but do you think they have had a significant impact in the international arena? Have they changed the way translators see their work?

LF: I do not know whether feminist theorization around translation has changed the way translators work, but it certainly made its way into translation studies on the international scale. There are many citations of feminist assessments and criticism and theories in academic work, and in the two recent anthologies of academic articles I put together-Translating Women (2011) and Translating Women: Different Voices and New Horizons (2017), there are many academic references. These anthologies present academic work on women writers whose work has been translated, or on the work of women translators, or on themes in books that might be deemed feminist or women-centered. In both books there are scholarly references to my work and to theoretical works by Barbara Godard, Sherry Simon, by all those Canadian scholars who were writing in the 1980s and the 1990s on the relationship between feminism and translation. The Canadian articles and books from the 1990s are still being cited regularly, whether in articles that come from China, Sri Lanka, Mexico, or Bulgaria. Because not much more has been done on the topic in other countries or on other language combinations: the original work was Canadian, and it was very convincing. Of course, people are adapting those ideas to their local situations now. For example in Translating Women, a very good article from Japan ("De-Feminizing Translation: To Make Women Visible in Japanese Translation" 
by Hiroko Furukawa) refers to the fact that certain texts on feminist translation in Canada insist on the need to make the feminine visible in language; the Japanese researcher suggests that in Japan they have to think about this problem somewhat differently, because Japanese literary language traditionally puts very effeminate language into the mouths of women. Even more so in translation than in original Japanese writing. The language is flowery, effeminate, and far removed from the reality of how women actually speak. In her view, it is time to make that language invisible.

AA: To make women more real by making them less feminine?

LF: Yes. To get rid of this exaggerated femininity that has become a convention in literary translation of texts around women. In this case, as you can see, they refer to the fact that Canadian scholars say one thing, which however has to be applied differently in the Japanese environment. It shows how political sensibilities are reflected in language. If feminism is a form of political activism, in which some people focus on the political impact of language, they will draw attention to the cases where language is misogynist or anti-feminist, and make corrections in linguistic terms.

AA: Yes, and the context will determine what kinds of corrections are required. It would be interesting to see if the theoretical impact of those writings actually changes how translation is taught to students, or the mainstream translation practices in the real professional world those students are supposed to go out into.

LF: Good question! I think it may have made some little difference, in fact Beverley Curran, who teaches in Japan is currently writing an article on that topic for the forthcoming Handbook on Translation, Feminism and Gender that I am co-editing with Hala Kamal from Cairo University. But there is always a backlash where feminist ideas arise. For instance, Carol Maier, a translator working with Spanish, wrote one of the earlier American texts about how she, as a feminist, had to make changes to the overly sexist content of the Cuban poems she was translating in the early 1980s. By 1996, however, she was translating a text by María Zambrano, a Spanish philosopher. The book Delirio y Destino: Los Veinte Años De Una Española (1989) is an account of twenty years in Zambrano's life, during which she fought hard for republicanism. And Maier decided that the fact that Zambrano was a woman was not important. So the title of the book became Delirium and Destiny. $A$ Spaniard in Her Twenties (1998). The interesting problem is that for many English speakers the word "Spaniard" implies a man. The possessive pronoun "her" comes as a surprise! Anyway, the translator wrote about this particular decision in her article on "woman-interrogated translation." In her view, feminism had gone too far and in many cases, an author's gender was of no consequence and did not need emphasis. So the book did not need to stress Zambrano's gender in the title. It was time to get away from such identity issues, and focus on the text. This was a hard-hitting antifeminist argument. By that point, American feminist writing had perhaps become too noisy, too partisan, too binary. This was also the time when Judith Butler started to take apart "simplistic" binary views in her book Gender Trouble, making things more fluid, in a way. I think, at that time, 
people were being put off by increasingly self-righteous feminist claims. Caroline Summers has written about this, too, in "Hostage to Feminism? The Success of Christa Wolf's Kassandra in its 1984 English Translation." In that article on Kassandra, Christa Wolf's book set in the Trojan War, which was translated into English and became a feminist phenomenon, Summers traces how this happened, how literary critics took it upon themselves to turn Christa Wolf into an American feminist. Which she was not. There seems to have been a certain strident appropriation of texts for the purposes of feminist argument that backfired.

AA: Do you think Canadian literature was generally informed by this upsurge in feminist literary and translation theories?

LF: Absolutely, and particularly in Quebec, which experienced it first-hand and much earlier. But English-speaking writers, too, embraced and developed feminist ideas. They represented feminist notions very soon via 'images of women.' Audrey Thomas, Margaret Atwood, Alice Munro, very much. And they were easily translatable into German, Hungarian, and other languages because they told stories, they had a narrative art. But so much depends on the "industrial" publishing context. Many Canadian books are not translated into French in Quebec; that work is done in France. When the authors hit big sales, larger publishing houses in France can offer more for the rights, and outbid smaller companies. Of course, Quebec translators then really enjoy pointing out where French translators have misunderstood aspects of Canadian life.

AA: By the way, how is Canadian reality understood and represented in literary translation these days? You have written about the images of the wild North and pristine nature that first introduced Canadian literature to German readers, but do you think there are currently any significant aspects that work in a similar way? For instance, anything you discovered in your research on Canada in Latin America?

LF: What we found in Latin America is that not many publishers are particularly interested in Canada. Translations are accidental, random events, driven mainly by occasional Canadian Studies academics with connections to Quebec. Quebec academics have pursued the idea that there is a special Latino connection to South America, and have built on this. One aspect that has worked really well, however, is the Mexico-Quebec connection. In theatre, the exchange between the two is very rich, and what seems to work well there is the common Catholic background, the importance of family in both societies, and the melodrama. And there is another similar stream, again between Mexico and Quebec, which is poetry translation. This is an exchange that was initiated by Noroit publishers, where Canadian and Mexican poets translate each other. But these are the two main activities in Canada-Latin America translation. The big works of fiction, especially anglophone writing, are translated in Spain, and then circulated in South America-or not, depending on how they sell in Spain. Again, the publishing decisions seem to be quite random. There is a web of 
influences and connections, and it is not easy to trace how particular works are selected to be translated and published.

AA: The market and public demand seem to be important factors, so what sells well must be translated.

LF: In general, yes. The most popular Canadian writer in Latin America right now is Malcolm Gladwell. His books have been translated into many languages, and the pop psychology he produces travels well. Is that Canadian? Does it represent Canada? What makes a Canadian writer? Does it come down to the language?

AA: Then, there may be immigrant writers who identify as Canadian but write in their own languages.

LF: Yes, that is another interesting question. We have talked about that briefly in regard to Germany, where there are so many writers from Eastern European and Central European countries. They are publishing books in German because of German scholarships they've received or German connections they have developed. Is that German literature? Will the Goethe-Institut fund translations of these books if the authors publish in Germany, but are originally from Russia or Georgia?

AA: Another question is whether we really need this ethnocentric perspective in literary translation?

LF: If you want funding, you do! Funding is attached to the so-called national principles and values, so yes, the ethnocentric perspective can hardly be avoided. But there are more and more people in translation studies who are very critical of this nationalistic aspect. They point out how translation maintains national values, and is often used and deployed to instill them as a form of cultural diplomacy.

AA: Yes, it is an important point of criticism and it brings me to the last thing I wanted to ask you about. How do you think cultural diplomacy will shape the future of literary translation?

LF: I think any changes that may happen will depend on economic conditions and on the importance of certain countries and languages. This will affect who translates what and who reads the translated texts. The importance of translation is becoming more visible these days, in Europe, for instance, where national funds are invested to promote translations, and efforts are being made to create an inter-European system of translations, beside the one-way stream of English into all those languages. This is great, but it only happens when there is money and political will. And, eventually, readers. As for the theory and practice, I think getting rid of the dead notion of faithfulness is something we should all work on. This is a challenge for everyone-the idea is so ingrained, and so impossible_-but it especially affects professional codes of ethics. 
AA: So, we need to make them acknowledge the theoretical advancements that have been made and change the professional requirements for translators?

LF: Yes, I think this will be a very important thing to do.

AA: A worthy aspiration for all of us working in translation. Thank you for the most insightful conversation, Dr. von Flotow, and for taking the time to share your thoughts with us. 